\title{
ANALISIS PENGARUH PERSEPSI PERMODALAN TERHADAP KINERJA USAHA DALAM MENINGKATKAN KEBERHASILAN UKM
}

\author{
Hardiyanto Wibowo \\ Fakultas Ekonomi dan Bisnis, Universitas Muhammadiyah Purwokerto \\ Email: hardiyantowb2d@gmail.com
}

\begin{abstract}
ABSTRAK
Usaha Kecil dan Menengah (UKM) merupakan tulang punggung sistem ekonomi kerakyatan. UKM berkontribusi dalam mengurangi masalah kesenjangan antar golongan pendapatan dan antar pelaku usaha, pengentasan kemiskinan dan penyerapan tenaga kerja. Konstribusi lainnya, UKM mempercepat perubahan struktural, meningkatkan perekonomian daerah dan ketahanan ekonomi nasional. Penelitian ini bertujuan untuk menguji pengaruh persepsi permodalan terhadap kinerja usaha dalam meningkatkan keberhasilan UKM. Data dalam penelitian ini diperoleh melalui kuesioner dan wawancara pada responden, yaitu UKM sentra knalpot Desa Sayangan Purbalingga. Hasil penelitian ini menemukan bahwa persepsi permodalan berpengaruh terhadap kinerja usaha. Hasil ini menunjukkan bahwa pentingnya persepsi permodalan dalam meningkatkan kinerja usaha UK.M Kata kunci: persepsi permodalan, kinerja UKM.
\end{abstract}

\section{PENDAHULUAN}

Pengembangan Usaha Kecil dan Menengah (UKM) di Indonesia merupakan salah satu prioritas dalam pembangunan ekonomi nasional. Keberadaan usaha mikro, kecil, dan menengah merupakan bagian yang tidak dapat dipisahkan dengan pembangunan ekonomi nasional maupun regional. Bentuk kepedulian pemerintah terhadap Usaha Kecil Menengah (UKM) tercermin dalam Undang-Undang RI nomor 9 tahun 1995, Instruksi Presiden RI nomor 10 tahun 1999 dan Keputusan Menteri Keuangan nomor 40/KMK.06/2003.

Hal ini karena usaha tersebut merupakan tulang punggung sistem ekonomi kerakyatan yang tidak hanya ditujukan untuk mengurangi masalah kesenjangan antar golongan pendapatan dan antar pelaku usaha, ataupun pengentasan kemiskinan dan penyerapan tenaga kerja. Lebih dari itu, pengembangannya mampu memperluas basis ekonomi dan dapat memberikan konstribusi dalam mempercepat perubahan struktural, yaitu meningkatnya perekonomian daerah dan ketahanan ekonomi nasional. Program dan kegiatan yang dilakukan pemerintah dalam upaya mengembangkan sektor UKM selama ini sungguh menggembirakan. Krisis ekonomi yang melanda Indonesia sejak pertengahan tahun 1997 lalu, yang diawali dengan krisis nilai tukar rupiah terhadap dolar AS dan krisis moneter telah mengakibatkan perekonomian Indonesia mengalami suatu resesi ekonomi yang besar. Krisis ini sangat berpengaruh negatif terhadap hampir semua lapisan/golongan masyarakat dan hampir semua kegiatan-kegiatan ekonomi di dalam negeri, tidak terkecuali kegiatan-kegiatan yang dilakukan dalam skala kecil dan menengah. Ditengahtengah proses restrukturisasi sektor korporat dan BUMN yang berlangsung lamban UKM Indonesia telah membuktikan perannya sebagai kontributor 
pertumbuhan ekonomi Indonesia, dengan membuktikan diri secara historis tahan terhadap krisis (Afiah, 2009).

UKM harus memiliki kinerja yang baik yang bertujuan untuk mempermudah manajer dalam pengambilan keputusan. Kinerja merupakan hasil kerja secara kualitas dan kuantitas yang dicapai oleh seseorang dalam menjalankan tugasnya sesuai dengan tanggung jawabnya, dan kinerja dapat diklasifikasikan sebagai kinerja manusia, kinerja mesin dan kinerja organisasi atau perusahaan, di mana hasil kegiatan kinerja dapat dilaksanakan secara efisiens dan efektifitas (Cantika, 2005).

Mulyadi (1997) menjelaskan bahwa organisasi pada dasarnya dijalankan oleh manusia, maka penilaian kinerja sesungguhnya merupakan penilaian atas perilaku manusia dalam menjalankan peran yang mereka mainkan di dalam organisasi. Menurut Wibisono (2006) evaluasi kinerja merupakan penilaian kinerja yang diperbandingkan dengan rencana atau standar-standar yang telah disepakati dan kinerja adalah penentuan secara periodik efektivitas operasional suatu oraganisasi, bagian organisasi, dam karyawannya berdasarkan sasaran, standard, dan kriteria yang telah ditetapkan sebelumnya.

Susanti (2008) mengatakan bahwa modal merupakan faktor utama yang tidak bisa diabaikan. Apabila penyediaan modal cukup sesuai dengan jumlah yang dibutuhkan, maka proses produksi akan lancar dan hasil ini sangat mempengaruhi kinerja usaha.

Rante (2010) menyatakan bahwa perilaku kewirausahaan memiliki peran strategis terhadap kinerja UKM agribisnis. Perilaku kewirausahaan telah mampu memanfaatkan peluang-peluang yang diberikan pemerintah untuk mengembangkan usaha yang dimiliki. Perilaku kewirausahaan hendaknya selalu ditingkatkan kapasitasnya agar dapat menjadikan UKM agribisnis memiliki produktivitas yang tinggi dan usaha yang handal.

Purnama (2010) menemukan bahwa motivasi usaha dengan indikator motivasi (keinginan pengusaha untuk berusaha), harapan (kesempatan yang diperoleh karena tercapainya tujuan usaha) dan insentif (imbalan yang diperoleh karena menjalankan usaha) berpengaruh positif terhadap kemampuan usaha dan keberhasilan usaha. Sedangkan kemampuan usaha (melalui indikator pengetahuan, sikap, keteramplilan dan kematangan emosional) berpengaruh positif terhadap keberhasilan usaha Industri kecil (dengan indikator efisiensi produksi dan perluasan produksi). Dengan pengaruhnya terhadap keberhasilan usaha variabel kemampuan usaha lebih dominan pengaruhnya terhadap keberhasilan usaha dibandingkan dengan motivasi usaha. Untuk itu perlu meningkatkan keberhasilan usaha industri kecil melalui kemampuan usaha dengan lebih mendahulukan meningkatkan sikap, kecerdasan emosional, keterampilan dan pengetahuan para pengusaha industri kecil dalam melakukan usahanya dan juga motivasi usaha dengan lebih mendahulukan meningkatkan harapan, motifasi dan insentif.

Banyaknya UKM yang berkembang di daerah Purbalingga memberikan peluang bagi pengusaha kerajinan besi khususnya pada pengusaha knalpot, dimana usaha tersebut sudah mendunia, bahkan sudah masuk persaingan global, sehingga pengusaha harus terus meningkatkan kinerja manajerialnya agar dapat bersaing di kalangan nasional dan internasional. Adapun banyak kendala dalam mencapai itu semua, yaitu kenaikan harga BBM membuat kalangan pengrajin knalpot di Purbalingga, Jawa Tengah, ikut khawatir dan terancam bangkrut. Jika 
pemerintah menaikkan harga BBM sebesar 30 persen akan mengakibatkan matinya usaha knalpot yang merupakan industri rumahan andalan Purbalingga, kenaikan harga BBM dapat memicu kenaikan harga bahan baku pembuatan knalpot berupa drum bekas dan baja stainless. Kondisi ini dapat mematikan industri knalpot di Purbalingga. Pada tahun 1990an di Purbalingga ada 100 pengusaha knalpot dengan karyawan mencapai 6.000 orang. Namun saat ini hanya sekitar 60 pengusaha dengan 4.000an karyawan. Sekarang pengrajin sulit menaikkan harga jual knalpot setiap kali terjadi kenaikan harga BBM karena sebagian besar bengkel enggan menaikkan harga knalpot lantaran komponen automotif lainnya mengalami kenaikan harga. Ada beberapa kendala yang mempengaruhi perkembangan produksi knalpot, salah satunya peralatan. Pemkab sedianya selalu membimbing UKM dengan memberikan dukungan permodalan dan peralatan. Permodalan digunakan untuk meningkatkan produksi. Peralatan untuk meningkatkan mutu produk. Kompetensi SDM masih di bawah rata-rata. Pesanan knalpot semakin meningkat seiring dengan perkembangan industri automotif. Namun, karena keterbatasan alat pencetak dan mesin serta SDM yang masih rendah. Sementara untuk mesin penggerak pembuat knalpot, pengrajin masih menggunakan fasilitas milik Pemkab Purbalingga yang ada di Unit Pelaksana Teknis (UPT) Logam (Suara Merdeka, 2012).

\section{TINJAUAN PUSTAKA DAN HIPOTESIS Modal}

Perusahaan membutuhkan modal dalam menjalankan aktifitasnya. Modal merupakan faktor yang sangat penting dalam perusahaan. Terdapat tiga jenis badan usaha, yaitu perusahaan dagang, perusahaan jasa, dan perusahaan manufaktur. Perusahaan memiliki kebutuhan modal yang berbeda-beda tergantung jenis usaha yang dijalankan. Menurut Brigham (2006) modal ialah jumlah dari utang jangka panjang, saham preferen, dan ekuitas saham biasa, atau mungkin pos-pos tersebut plus utang jangka pendek yang dikenakan bunga. Standar Akuntansi Keuangan (IAI, 2007) mendefinisikan modal sebagai hak residual atas asset perusahaan setelah dikurangi semua kewajiban. Sedangkan, sumber modal sendiri berasal dari:

1. Sumber Intern

Modal yang berasal dari sumber intern adalah modal atau dana yang di bentuk atau dihasilkan sendiri di dalam perusahaan."Alasan perusahaan menggunakan sumbar dana intern yaitu:

a. Dengan dana dari dalam perusahaan maka perusahaan tidak mempunyai kewajiban untuk membayar bunga maupun dana yang di pakai.

b. Setiap saat tersedia jika diperlukan.

c. Dana yang tersedia sebagian besar telah memenuhi kebutuhan dana perusahaan.

d. Biaya pemakaian relatif murah".

2. Sumber Ekstern

Modal yang berasal dari sumber ekstern adalah sumber yang berasal dari luar perusahaan. Alasan perusahaan menggunakan sumber dana ekstern adalah:
a. Jumlah dana yang digunakan tidak terbatas.
b. Dapat di cari dari berbagai sumber.
c. Dapat bersifat fleksibel. 


\section{Kinerja Usaha}

Madura (2001) menjelaskan bahwa kinerja bisnis dilihat dari sudut pemilik usaha yang menanamkan modalnya pada suatu perusahaan memusatkan diri pada dua kriteria untuk mengukur kinerja perusahaan: 1) imbalan atas penanaman modalnya dan 2) risiko dari penanaman modal mereka. Karena strategi bisnis yang harus dilaksanakan oleh manajer harus ditujukan untuk memuaskan pemilik bisnis. Para manajer harus menentukan bagaimana strategi bisnis yang bermacam-macam akan mempengaruhi imbalan atas penanaman modal perusahaan dan resikonya.

Menurut Mulyadi (1997) informasi akuntansi yang dipakai sebagai ukuran kinerja manajer pusat pendapatan adalah pendapatan. Sedangkan informasi yang dipakai sebagai ukuran kinerja manajer pusat adalah biaya. Begitu pun dengan pusat laba. Pusat laba adalah pusat pertanggungjawaban yang manajernya diberi wewenang untuk mengendalikan pendapatan dan biaya pusat pertanggungjwaban tersebut. Karena laba, yang merupakan selisih antara pendapatan dan biaya, tidak dapat berdiri sendiri sebagai ukuran kinerja pusat laba, maka laba perlu dihubungkan dengan investasi yang menghasilkan laba tersebut. Umumnya, mengukur kinerja pusat laba digunakan dua ukuran yang menghubungkan laba yang diperoleh pusat laba denga pusat investasi yang digunakan untuk menghasilkan laba: Return on Investment (ROI) dan Residual Income (RI). Ukuran yang lain dapat digunakan untuk mengukur kinerja manajer pusat laba adalah produktivitas.

Mulyadi (1997) menjelaskan bahwa organisasi pada dasarnya dijalankan oleh manusia, maka penilaian kinerja sesungguhnya merupakan penilaian atas perilaku manusia dalam menjalankan peran yang mereka mainkan di dalam organisasi. Menurut Wibisono (2006) evaluasi kinerja merupakan penilaian kinerja yang diperbandingkan dengan rencana atau standar-standar yang telah disepakati. Penilaian kinerja adalah penentuan secara periodik efektivitas operasional suatu oraganisasi, bagian organisasi, dam karyawannya berdasarkan sasaran, standard, dan kriteria yang telah ditetapkan sebelumnya.

\section{Pengaruh Persepsi Permodalan terhadap Kinerja Usaha}

Modal usaha adalah kelebihan aktiva lancar terhadap utang jangka pendek. Kelebihan ini disebut modal usaha bersih (net working capital). Kelebihan ini merupakan jumlah aktiva lancar yang berasal dari utang jangka panjang dan modal sendiri (Munizu, 2010). Susanti (2008) menyatakan bahwa modal berpengaruh terhadap kinerja usaha. Berdasarkan uraian ditas maka hipotesis dalam penelitian ini, yaitu:

H1: Persepsi permodalan berpengaruh terhadap kinerja usaha. 


\section{METODE PENELITIAN} Jenis Penelitian

Penelitian ini berupa studi empiris, yaitu suatu jenis penelitian dengan mempelajari buku-buku, jurnal dan catatan yang berkaitan dengan masalah yang sedang diteliti. Hasil studi ini diharapkan akan diperoleh informasi dan data-data yang relevan serta akurat yang berkaitan dengan penelitian ini, serta bertujuan untuk memberi penjelasan mengenai analisis pengaruh persepsi permodalan, perilaku kewirausahaan dan motivasi terhadap kinerja usaha pada sentra knalpot Desa Sayangan Purbalingga.

\section{Populasi dan Sampel}

Populasi dalam penelitian ini adalah UKM sentra knalpot Desa Sayangan Purbalingga. Sampel yang digunakan dalam penelitian ini adalah pemilik/ pengelola pada bengkel knalpot yang berada di Purbalingga, dan lebih tepatnya di lingkup Desa Sayangan. Kuisioner akan diberikan kepada pemilik / peengelola bengkel knalpot yang terpilih sebagai sampel.

Teknik pengambilan sampel dalam penelitian ini adalah purposive sampling dengan kriteria:

1. Bengkel knalpot yang terdaftar di UMKM Purbalingga dan paguyuban.

2. Pemilik / pengelola bengkel knalpot minimal 2 tahun.

3. Modal awal minimal 5 juta.

4. Karyawan minimal 2 orang.

5. Bengkel minimal 2 tahun.

6. Laba minimal 25 juta / tahun.

\section{Metode Pengambilan Data}

Metode pengambilan data dalam penelitian ini adalah dengan menggunakan kuesioner yaitu metode pengumpulan data yang pengumpulan datanya dilakukan dengan cara memberikan kuesioner kepada responden untuk dijawabnya. Kuesioner diberikan secara langsung kepada pemilik usaha.

\section{Definisi operasional dan pengukuran variabel}

Dalam penelitian, data diperoleh dari jawaban responden terhadap pertanyaan yang menyangkut kinerja usaha terhadap variabel bebas persepsi permodalan $\left(\mathrm{X}_{1}\right)$, dan variabel terkait kinerja usaha $(\mathrm{Y})$.

a. Persepsi Permodalan $\left(\mathrm{X}_{1}\right)$

Modal usaha adalah kelebihan aktiva lancar terhadap utang jangka pendek. Kelebihan ini disebut modal usaha bersih (net working capital). Kelebihan ini merupakan jumlah aktiva lancar yang berasal dari utang jangka panjang dan modal sendiri (Munizu, 2010). Kuesioner di modifikasi oleh Putri (2011). Dalam penelitian ini terdapat 2 indikator yang akan diukur, yaitu modal internal dan modal eksternal. Pengukuran dengan skala likert yaitu: Sangat Setuju (SS), Setuju (S), Netral (N), Tidak Setuju (TS), Sangat Tidak Setuju (STS).

b. Kinerja Usaha (Y)

Kinerja Usaha adalah untuk menilai seberapa baik aktivitas yang berhasil dicapai (Lingle dan Schiemann, 1996). Kuesioner di modifikasi oleh Novitasari (2011). Dalam penelitian ini terdapat 4 indikator yang akan diukur, yaitu kualitas kerja, kuantitas kerja, kemampuan kerja, dan tanggung jawab. Pengukuran dengan 
skala likert yaitu: Sangat Setuju (SS), Setuju (S), Netral (N), Tidak Setuju (TS), Sangat Tidak Setuju (STS).

\section{Metode Analisis Data}

Penelitian ini melakukan beberapa tahapan untuk analisis data, yang dimulai dari pengujian validitas dan reliabilitas. Kemudian melakukan uji asumsi klasik yang terdiri dari Uji Normalitas, Uji Multikolinearitas, dan Uji Heteroskedastisitas. Selain itu, penelitian ini juga melakukan uji non response bias. Kemudian, pengujian hipotesis dalam penelitian ini menggunakan uji regresi dengan model regresi sebagai berikut:

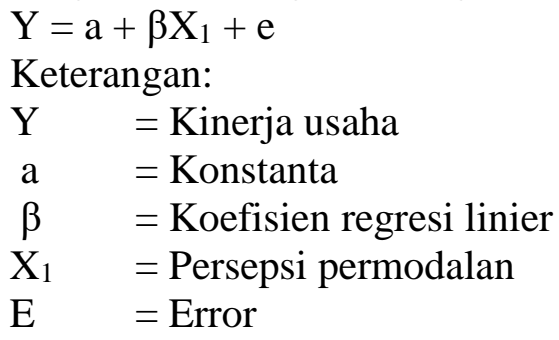

\section{HASIL PENELITIAN DAN PEMBAHASAN}

Gambaran Umum Responden

1. Dari hasil penelitian untuk data tabulasi penyebaran kuesioner pada sentra knalpot Desa Sayangan Purbalingga, sebagai berikut :

\section{Tabel 1}

Data tabulasi penyebaran kuesioner pada sentra knalpot Desa Sayangan Purbalingga.

\begin{tabular}{clc}
\hline No & \multicolumn{1}{c}{ Keterangan } & Jumlah \\
\hline $\mathbf{1}$ & $\begin{array}{l}\text { Jumlah kuesioner yang didistribusikan } \\
\text { secara langsung pada saat penyebaran }\end{array}$ & 65 \\
$\mathbf{2}$ & $\begin{array}{l}\text { Jumlah kuesioner yang diisi pada saat } \\
\text { penyebaran secara langsung }\end{array}$ & 57 \\
$\mathbf{3}$ & $\begin{array}{l}\text { Jumlah kuesioner yang tidak bisa } \\
\text { didistribusikan }\end{array}$ & 8 \\
$\mathbf{4}$ & $\begin{array}{l}\text { Jumlah kuesioner yang tidak masuk dalam } \\
\text { kriteria }\end{array}$ & 17 \\
$\mathbf{5}$ & $\begin{array}{l}\text { Jumlah kuesioner yang masuk dalam } \\
\text { penelitian dan yang dianalisis }\end{array}$ & 40 \\
\hline
\end{tabular}

Sumber: Data diolah (Lampiran 2)

Berdasarkan tabel 4.1 diatas dapat diperoleh gambaran bahwa dari 65 kuesioner yang peneliti distibusikan ke 57 bengkel knalpot, sebanyak 40 kuesioner yang mendapat jawaban dan masuk dalam analisis peneliti, sedangkan 17 kuesioner tidak masuk kriteria dan 8 kuesinoner tidak didistribusikan.

2. Dari hasil penelitian untuk data kriteria penyebaran kuesioner pada sentra knalpot Desa Sayangan Purbalingga, sebagai berikut :

a. Gambaran Umum Responden Berdasarkan Modal Awal

Berdasarkan Modal Awal, responden dapat dikelompokkan sebagai berikut : 
Tabel 2

Gambaran Umum Responden Berdasarkan Modal Awal

\begin{tabular}{ccc}
\hline \multirow{2}{*}{ Modal Awal } & \multicolumn{3}{c}{ Jumlah } \\
\cline { 2 - 3 } & (Orang) & $\mathbf{( \% )}$ \\
\hline 5 jt $-10 \mathrm{jt}$ & - & - \\
$10 \mathrm{jt}-15 \mathrm{jt}$ & 7 & 17.5 \\
$15 \mathrm{jt}-20 \mathrm{jt}$ & 2 & 5 \\
$20 \mathrm{jt}-25 \mathrm{jt}$ & 18 & 45 \\
Lebih dari 25jt & 13 & 32.5 \\
\hline Jumlah & $\mathbf{4 0}$ & $\mathbf{1 0 0}$ \\
\hline
\end{tabular}

Sumber: Data diolah (Lampiran 2)

Berdasarkan Tabel 4.2 dapat diketahui bahwa modal awal responden palaing banyak adalah $20 \mathrm{jt}$ - $25 \mathrm{jt}$ yaitu sebanyak 18 orang atau $45 \%$, sedangkan jumlah paling sedikit adalah responden dengan modal awal dari $15 \mathrm{jt}$ - 20 jt yaitu sebanyak 2 orang atau 5\% dari keseluruhan jumlah responden.

b. Gambaran Umum Responden Berdasarkan Jumlah Tenaga Kerja

Berdasarkan jumlah tenaga kerja, responden dapat dikelompokkan sebagai berikut :

Tabel 3

Gambaran Umum Responden Berdasarkan Jumlah Tenaga Kerja

\begin{tabular}{ccc}
\hline Jumlah Tenaga & \multicolumn{2}{c}{ Jumlah } \\
\cline { 2 - 3 } Kerja & (Bengkel) & $\mathbf{( \% )}$ \\
\hline $2-3$ & 2 & 5 \\
$3-4$ & 4 & 10 \\
$4-5$ & 19 & 47.5 \\
$5-6$ & 9 & 22.5 \\
Lebih dari 6 & 6 & 15 \\
\hline Jumlah & $\mathbf{4 0}$ & $\mathbf{1 0 0}$ \\
\hline
\end{tabular}

Sumber: Data diolah (Lampiran 2)

Berdasarkan Tabel 4.3 dapat diketahui bahwa jumlah tenaga kerja responden paling banyak adalah 4 - 5 yaitu sebanyak 19 orang atau $47.5 \%$, sedangkan jumlah paling sedikit adalah responden dengan jumlah tenaga kerja 2 - 3 yaitu 2 orang atau 5\% dari keseluruhan jumlah responden.

c. Gambaran Umum Responden Berdasarkan Umur Usaha

Berdasarkan umur usaha, responden dapat dikelompokkan sebagai berikut :

Tabel 4

Gambaran Umum Responden Berdasarkan Umur Usaha

\begin{tabular}{ccc}
\hline \multirow{2}{*}{ Umur Usaha } & \multicolumn{2}{c}{ Jumlah } \\
\cline { 2 - 3 } & (Orang) & $\mathbf{( \% )}$ \\
\hline $2-4$ thn & - & - \\
$4-6$ thn & 1 & 2.5 \\
$7-10$ thn & 14 & 35 \\
$11-15$ thn & 4 & 10 \\
Lebih dari 15 thn & 21 & 52.5 \\
\hline Jumlah & $\mathbf{4 0}$ & $\mathbf{1 0 0}$ \\
\hline
\end{tabular}

Sumber: Data diolah (Lampiran 2) 
Berdasarkan Tabel 4.4 dapat diketahui bahwa jumlah responden terbanyak memiliki umur usaha $>15$ tahun yaitu sebanyak 21 orang atau $23.5 \%$, sedangkan jumlah paling sedikit adalah responden dengan umur usaha 4 - 6 tahun yaitu sebanyak 1 orang atau $2.5 \%$ dari keseluruhan jumlah responden.

\section{d. Gambaran Umum Responden Berdasarkan Laba Usaha}

Berdasarkan laba usaha, responden dapat dikelompokkan sebagai berikut:

Tabel 5

Gambaran Umum Responden Berdasarkan Laba Usaha Tahun Lalu

\begin{tabular}{ccc}
\hline \multirow{2}{*}{ Laba Usaha Tahun Lalu } & \multicolumn{2}{c}{ Jumlah } \\
\cline { 2 - 3 } & (Orang) & $\mathbf{( \% )}$ \\
\hline $25 \mathrm{jt}-50 \mathrm{jt}$ & 29 & 72.5 \\
$50 \mathrm{jt}-75 \mathrm{jt}$ & 4 & 10 \\
$75-100 \mathrm{jt}$ & 6 & 15 \\
$100 \mathrm{jt}-125 \mathrm{jt}$ & 1 & 2.5 \\
Lebih dari 125jt & - & - \\
\hline Jumlah & $\mathbf{4 0}$ & $\mathbf{1 0 0}$
\end{tabular}

Sumber: Data diolah (Lampiran 2)

Berdasarkan Tabel 4.5 dapat diketahui bahwa jumlah responden terbanyak memiliki umur usaha $>15$ tahun yaitu sebanyak 21 orang atau $23.5 \%$, sedangkan jumlah paling sedikit adalah responden dengan umur usaha 4 - 6 tahun yaitu sebanyak 1 orang atau $2.5 \%$ dari keseluruhan jumlah responden.

Dari data kriteria di atas tentang modal awal, jumlah karyawan, umur usaha, dan laba per tahun semuanya masuk dalam kriteria dan selanjutnya data bisa di olah di SPSS.

\section{Hasil Analisis dan Pembahasan}

Analisis dan pembahasan yang akan dilakukan dalam penelitian ini adalah untuk mengetahui pengaruh Persepsi Permodalan (X) terhadap Kinerja Usaha (Y) pada pengusaha sentra knalpot Desa Sayangan Purbalingga.

\section{A. Uji Instrumen Data}

Sebelum melakukan pengujian hipotesis penelitian terlebih dahulu melakukan pengujian terhadap data penelitian. Pengujian data ini dilakukan dengan menggunakan uji validitas dan reliabilitas.

\section{Uji Validitas}

Validitas alat ukur yaitu suatu cara untuk melihat apakah instrument yang akan digunakan dalam penelitian dapat menjalankan fungsi ukurnya (Azwar, 2000). Pendekatan yang digunakan dalam uji validitas (analisis butir) pada penelitian ini adalah dengan membandingkan nilai $\mathrm{r}$ (Corrected Item-Total Correlation) dengan $\mathrm{r}$ tabel sehingga dapat di ketahui item pertanyaan mana yang gugur dan sahih. Item butir pertanyaan sahih jika r-hitung $>$ r-tabel, dan sebaliknya (Triton, 2006). Hasil pengujian yang telah dilakukan terhadap masing-masing variabel sebagai berikut: 
a. Variabel Kinerja Usaha

Tabel 6

Hasil Uji Validitas Variabel Kinerja Usaha (Y)

\begin{tabular}{ccc}
\hline Item Pertanyaan & Nilai pearson Correlation & Keterangan \\
\hline Q1 & $0.619^{* *}$ & Valid \\
Q2 & $0.494^{* *}$ & Valid \\
Q3 & $0.676^{* *}$ & Valid \\
Q4 & $0.569^{* *}$ & Valid \\
Q5 & $0.579^{* *}$ & Valid \\
Q6 & $0.557^{* *}$ & Valid \\
Q7 & $0.665^{* *}$ & Valid \\
Q8 & $0.642^{* *}$ & Valid \\
\hline
\end{tabular}

Sumber : Data diolah (Lampiran 3)

Dari tabel 4.6 di atas dapat disimpulkan keseluruhan item pertanyaan variabel kinerja usaha $(\mathrm{Y})$ dinyatakan valid karena nilai pearson Correlation > r-tabel 0,312 sehingga data yang di peroleh dapat mengukur ketepatan dan kecermatan alat ukur dalam melakukan fungsi ukurnya dan dapat digunakan dalam proses estimasi berikutnya.

b. Variabel Persepsi Permodalan

Tabel 7

Hasil Uji Validitas Variabel Modal Usaha (X1)

\begin{tabular}{ccc}
\hline Item Pertanyaan & Nilai pearson Correlation & Keterangan \\
\hline Q1 & $0.602^{* *}$ & Valid \\
Q2 & $0.888^{* *}$ & Valid \\
Q3 & $0.613^{* *}$ & Valid \\
Q4 & $0.888^{* *}$ & Valid \\
\hline
\end{tabular}

Sumber : Data diolah (Lampiran 3)

Dari tabel. 4.7 di atas dapat disimpulkan keseluruhan item pertanyaan variabel modal usaha (X1) dinyatakan valid karena nilai pearson Correlation > r-tabel 0,312 sehingga data yang di peroleh dapat mengukur ketepatan dan kecermatan alat ukur dalam melakukan fungsi ukurnya dan dapat digunakan dalam proses estimasi berikutnya.

2. Reliabilitas

Reliabilitas adalah alat ukur yang berhubungan dengan sejauhmana hasil dari suatu pengukuran dapat dipercaya. Suatu hasil pengukuran dapat dipercaya apabila dalam beberapa kali pelaksanaan hasil yang di peroleh relatif sama (Azwar, 2001). Pendekatan yang digunakan dalam uji reliabilitas pada penelitian ini adalah dengan pendekatan Internal Consistensy dengan tekhnik alpha dari cronbach, dengan nilai hasil alpha harus diatas 0,6. Dari hasil uji reliabilitas diperoleh hasil sebagai berikut:

\section{Tabel 8}

Hasil Uji Reliabilitas

\begin{tabular}{rccc}
\hline Variabel & $\mathrm{r}_{\text {hitung }}$ & $\mathrm{r}_{\text {batas }}$ & Keterangan \\
\hline Kinerja Usaha & 0.746 & 0.6 & Reliabel \\
Modal Usaha & 0.745 & 0.6 & Reliabel \\
\hline
\end{tabular}

Sumber : Data diolah (Lampiran 3) 
Dari tabel 4.10 di atas dapat disimpulkan bahwa seluruh variabel dinyatakan reliabel, yang ditunjukan dengan nilai $r_{\text {hitung }}$ masing-masing variabel $>r_{\text {batas }}: 0,6$. Sehingga data yang diperoleh dapat menunjukan ukuran kestabilan dan konsistensi dari konsep ukuran instrumen dan dapat digunakan dalam proses estimasi berikutnya.

\section{Pengujian Hipotesis}

Pengujian hipotesis penelitian ini menggunakan analisis regresi. Hasil olah data perhitungan regresi linear dengan program SPSS dapat dilihat dalam tabel 12.

Tabel 12

Analisis Regresi Linier

\begin{tabular}{lcc}
\hline & Model & B \\
\hline 1 (Constant) & 9,780 \\
Modal & 0.845 \\
\hline
\end{tabular}

Sumber : Data diolah (Lampiran 3)

Berdasarkan hasil pada tabel.4.14 dapat dibuat persamaan regresi sebagai berikut :

$$
\begin{aligned}
& \mathrm{Y}=9,780+0,845 \mathrm{X} 1+\mathrm{e} \\
& \text { Keterangan : } \\
& \mathrm{Y} \quad=\text { Kinerja Usaha } \\
& \mathrm{X} 1 \quad=\text { Persepsi permodalan } \\
& \mathrm{e} \quad=\text { variabel pengganggu (error) }
\end{aligned}
$$

Dari persamaan regresi tersebut diatas, dapat dijelaskan beberapa hal sebagai berikut :

1. Konstanta sebesar 9,780 artinya jika persepsi permodalaan, nilainya 0 , maka kinerja usaha nilainya sebesar 9,780.

2. Koefisien regresi variabel persepsi permodalan sebesar 0,845 , bernilai positif artinya jika persepsi permodalan mengalami kenaikan maka kinerja usaha juga akan mengalami kenaikan.

\section{Uji Koefisien Determinan $\left(\mathbf{R}^{2}\right)$}

Analisis determinan digunakan untuk mengukur seberapa jauh kemampuan model dalam menerangkan variasi variabel dependen. Nilai koefisien determinan adalah antara nol dan satu.

Tabel 13

Hasil Uji R square

\begin{tabular}{lc}
\hline Model & Adjusted R Square \\
\hline 1 & 0,508 \\
\hline Sumber : Data diolah (Lampiran 3) & \\
Berdasarkan tabel di atas nilai Adjust R Square sebesar 0,508 \\
yang berarti 50,8\% variasi kinerja usaha dapat dijelaskan oleh persepsi \\
permodalan. Sedangkan, sisanya $(100 \%-50,8 \%=49,2 \%)$ dijelaskan \\
oleh sebab yang lain di luar model.
\end{tabular}

\section{Uji t}

Untuk menentukan signifikasi pengaruh secara parsial variabel independen dapat di lihat pada tabel 4.11 berikut ini : 
Tabel 4.17

Hasil Uji t

\begin{tabular}{ccc}
\hline Model & t & Sig \\
\hline Persepsi permodalan & 2,057 & 0,047 \\
\hline Sumber : Data diolah (Lampiran 3) & &
\end{tabular}

1) Pengujian Hipotesis

Berdasarkan output regresi diatas diperoleh nilai t statistik variabel persepsi permodalan (X1) sebesar 2,057 lebih besar dari nilai t tabel 1,706. Output regresi diatas juga menunjukkan bahwa nilai signifikan 0,047 lebih kecil dari nilai $\alpha(0,05)$. Dengan demikian, maka hipotesis yang menyatakan bahwa persepsi permodalan berpengaruh terhadap kinerja usaha, diterima. Secara grafik dapat dijelaskan dalam gambar sebagai berikut :

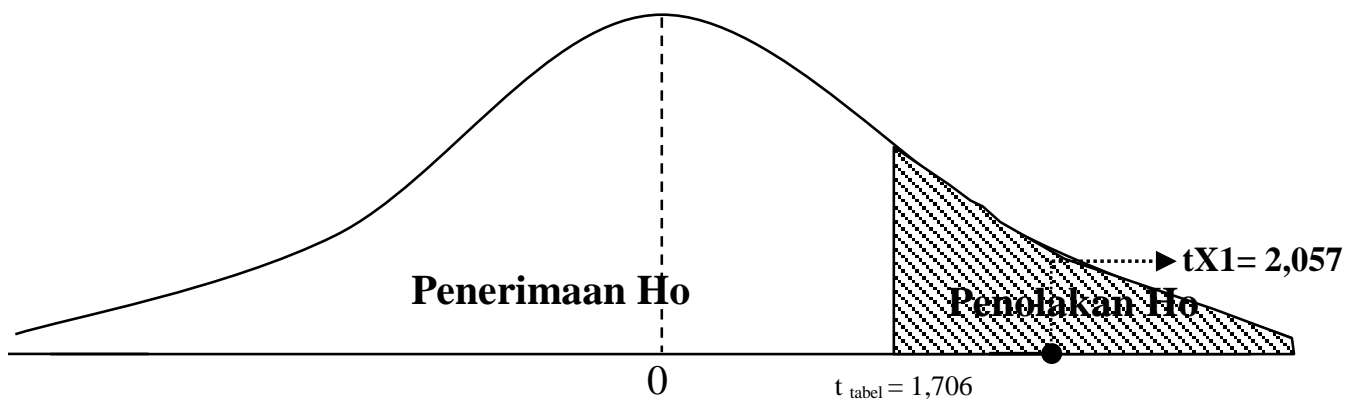

Gambar 4.1. Kriteria Pengujian Hipotesis

Modal usaha yang tinggi dialami bengkel-bengkel knalpot di Purbalingga, akan meningkatkan kinerja usaha pada suatu bengkel. Modal usaha yang tinggi didukung oleh perilaku kewirausahaan dan motivasi yang tinggi akan dapat meningkatkan kinerja usaha. Pemilik UKM dapat menjalankan suatu kegiatan atau perencanaan serta mengembangkan usahanya, sehingga dapat meningkatkan keberhasilan usaha,

Pada hasil hipotesis membuktikan bahwa persepsi permodalan berpengaruh terhadap kinerja usaha. Hasil penelitian ini mendukung Susanti (2008), yang menyatakan bahwa modal berpengaruh terhadap kinerja usaha.

\section{KESIMPULAN}

Dari hasil estimasi pengaruh persepsi permodalan (X) terhadap kinerja usaha (Y) dengan menggunakan 40 responden sebagai sampel dapat diketahui bahwa hipotesis diterima. Persepsi permodalan berpengaruh terhadap kinerja usaha. Hasil analisis Uji $\mathrm{t}$ dari model regresi menunjukkan nilai signifikansi sebesar $0,047<\alpha(0,05)$ dan nilai koefisien regresi 2,057 lebih besar dari t-tabel 1,706. Dengan demikian $\mathrm{H}_{\mathrm{o}}$ ditolak dan $\mathrm{H}_{\mathrm{a}}$ diterima.

Berdasarkan penelitian yang telah dilakukan, peneliti memberikan saran pada Pemerintah kabupaten Purbalingga, maupun lembaga keuangan baik perbankan maupun koperasi, diperlukan adanya kerjasama antara pemerintah dan pengusaha besar serta kelompok UKM, untuk membuat suatu program pemberdayaan kepada UKM sentra knalpot Sayangan agar lebih berdaya dan produktif. Salah satunya melalui pemberian kredit dengan proses yang mudah 
dengan bunga yang rendah dan dapat dijangkau oleh UKM sentra knalpot Sayangan.

\section{DAFTAR PUSTAKA}

Afiah, 2009. Pengertian Dan Kriteria UKM, NAD

Agnes Sawir. 2005. Analisis Kinerja Keuangan dan Perencanaan Keuangan Perusahaan, Jakarta : Penerbit PT. Gramedia Pustaka Utama

Ardiana, Brahmayanti, Subaedi, 2010. Kompetensi SDM UKM dan Pengaruhnya Terhadap Kinerja UKM di Surabaya. Jurnal Manajemen dan Kewirausahaan. Surabaya.

As'ad, M., 1993, Psikologi Industri, Edisi Keempat, Penerbit: Liberty, Yogjakarta.

Bambng, Riyanto. 2001. Dasar-Dasar Pembelajaran Perusahaan. Yogyakarta: BPFE

Bhave, M.P., 1993. A Process Model of Entrepre-neurial Ventura Creation. Journal of Business Venturing.

Brigham, Eugene F., and Michael C. Ehrhardt, (2006), Financial Management: Theory and Practice, Eleventh Edition, South-Western, Australia: Thomson Learning.

Ghozali, Imam. 2009. Ekonometrika Teori, Konsep dan Aplikasi dengan SPSS 17, BP UNDIP, Semarang.

Gray, Collin (2002), judul Entrepreneurship resistence to change and Growth in small firms (USA),

Hasibuhan Malayu, SP, 2000, Manajemen Sumber Daya Manusia, Edisi Revisi, Cetakan Kedua, Jakarta, Bumi Aksara.

Madura, Jeff. (2001). Pengantar Bisnis. Buku Dua. Jakarta. Penerbit Salemba Empat.

Munizu, Musran, 2010. Pengaruh Faktor-Faktor Eksternal dan Internal Terhadap Kinerja Usaha Mikro dan Kecil (UMK) di Sulawesi Selatan. Jurnal Manajemen dan Kewirausahaan. Sulawesi Selatan.

Mulyadi dan setyawan, 1999. Sistem Perancangan Dan Pengendalian Manajemen: System Pelipat Ganda Kinerja Perusahaan. Salemba. Jakarta.

Novitasari, 2011. Pengaruh Perilaku Kwirausahaan Pada Kinerja Usaha. Universitas Airlangga. Ekonomi Manajemen.

Putri, Dewi. 2011. Modal Usaha Pada Kinerja Usaha. Universitas Indonesia. Ekonomi.

Purnama, Chamdan, 2010. Motivasi dan Kemampuan Usaha Dalam Meningkatkan Keberhasilan Usaha Industri Kecil (Studi Pada Industri Kecil Di Jawa Timur). Jurnal Manajemen dan Kewirausahaan. Surabaya.

Rante, Yohanes, 2010. Pengaruh Budaya Etnis dan Perilaku Kewirausahaan Terhadap Kinerja Usaha Mikro Kecil Agribisnis di Provinsi Papua. Jurnal Manajemen dan Kewirausahaan. Papua.

Robbins, S.R., 2001, Perilaku Organisasi: Konsep Kontroversi Aplikasi, Jilid Pertama, Alih Bahasa: Pearson Educations Asia Pte. Ltd. Dan PT. Prenhallindo, Penerbit PT. Prenhallindo, Jakarta.

Santoso, Singgih. 2010. Statistik Multivariat. Jakarta : PT Elex Media Komputindo. 
Santoso, Singgih. 2010. Statistik Parametrik. Jakarta : PT Elex Media Komputindo.

Singarimbun M. Dan Sofian Effendi. 1995. Metode Penelitian Survey. Jakarta : LP3ES.

Siswanto, Bedjo. 1989. Manajemen Tenaga Kerja. Cetakan Kedua. Bandung: Sinar Baru.

Suara merdeka. 11 March 2012. Kenaikan Harga BBM, Perajin Knalpot Purbalingga Khawatir Bangkrut. Purbalingga.com.

Sudjana. 2005. Metode Statistik. Edisi Kelima. Tarsito. Bandung.

Sugiono. 2007. Statistik Untuk Penelitian. Bandung : Alfabeta

Susanti, Desi, 2008. Faktor-faktor yang Mempengaruhi Kinerja Usaha Kecil Kerupuk Sanjai. Jurnal Bisnis \& Manajemen. Bukittinggai.

Undang-undang No.9 Tahun 1995 Tentang Usaha Kecil.

Undang-undang RI No.25 Tahun 1997 Tentang Ketentuan Umum Mengenai Tenaga Kerja.

Wibisono, Dermawan.2006. Manajemen Kinerja, Konsep, Desain, dan Teknik Meningkatkan Daya Saing Perusahaan. Erlangga. Jakarta.

Yuli, Sri Budi Cantika, 2005. Manajemen Sumber Daya Manusia, UMM Press, Malang 